\title{
Oral health status in relation to socioeconomic and behavioral factors among pregnant women: a community- based cross-sectional study
}

\author{
Marzie Deghatipour ${ }^{1}$ (D), Zahra Ghorbani ${ }^{2^{*}}$ (D), Shahla Ghanbari ${ }^{3}$, Shahnam Arshi ${ }^{4}$, Farnaz Ehdayivand ${ }^{5}$,
} Mahshid Namdari ${ }^{6}$ and Mina Pakkhesal ${ }^{7}$

\begin{abstract}
Background: Oral health of women during pregnancy is an important issue. Not only it can compromise pregnancy outcomes, but also it may affect their newborn's overall health. The aim of this study was to assess the oral health status and associated factors in pregnant women.

Methods: A cross-sectional study was conducted amongst 407 pregnant women in the second and third trimester of pregnancy in Varamin, Iran. Oral health status was examined, and demographic, socioeconomic status and dental care behavior data were collected. Oral health indices included periodontal pocket, bleeding on probing (BOP) and decayed, missed, filled teeth (DMFT). Regression analysis of DMFT was used to study the association between demographic, dental care behaviors indicators and outcome variables using the count ratios (CR) and 95\% confidence intervals (Cl).

Results: The mean (SD, Standard Deviation) age of participants was 27.35 (5.57). Daily brushing, flossing habit were observed in 64.1, and 20.6\% of mothers, respectively. Mean (SD) of DMFT, D, M, F were 10.34(5.10), 6.94(4.40), 2.22 (2.68) and 1.19(2.23), respectively. Women older than 35 years had significantly more DMFT [CR $=1.35(95 \% \mathrm{Cl} 1.13$; 1.60)], less D [CR $=0.75(95 \% \mathrm{Cl} 0.59 ; 0.94)]$, and more M $[C R=3.63$ (95\% Cl 2.57; 5.14)] compared to women under 25 years after controlling for education and dental care behaviors. Women with academic education had significantly less decayed teeth [CR $=0.63(95 \% \mathrm{Cl} 0.48 ; 0.84)]$, compared to women with under 12 years of education.
\end{abstract}

Conclusions: Oral health status of pregnant women was not satisfactory, having an average of seven decayed teeth in their mouth.

Keywords: Oral health, Pregnant women, Dental care behaviors

\section{Background}

Pregnancy is a natural process accompanied with considerable physiological and hormonal changes in women's body, including oral cavity [1]. There are many common oral problems in pregnancy such as pregnancy gingivitis, benign gingival lesions, tooth mobility, tooth erosion, dental caries, and periodontitis [2]. Oral health

\footnotetext{
*Correspondence: Dryaszgh@yahoo.com

${ }^{2}$ Community Oral Health Department, School of Dentistry, Shahid Beheshti University of Medical Sciences, Daneshjoo Blvd, Tehran, IR 19834, Iran Full list of author information is available at the end of the article
}

is an important issue to general health of both the expectant woman and her infant [3]. Evidence showed that insufficient of oral health care during pregnancy can have negative outcomes for both mothers and their newborns [4].

According to a systematic review, the relationship between pregnancy and gingivitis was confirmed. The characteristics of pregnancy-associated gingivitis are similar to common plaque-related gingivitis but with more severity; the severity being correlated with blood steroid hormone levels [3]. Periodontal disease during

(c) The Author(s). 2019 Open Access This article is distributed under the terms of the Creative Commons Attribution 4.0 International License (http://creativecommons.org/licenses/by/4.0/), which permits unrestricted use, distribution, and reproduction in any medium, provided you give appropriate credit to the original author(s) and the source, provide a link to the Creative Commons license, and indicate if changes were made. The Creative Commons Public Domain Dedication waiver (http://creativecommons.org/publicdomain/zero/1.0/) applies to the data made available in this article, unless otherwise stated. 
pregnancy has been criticized to be associated with adverse perinatal outcomes, including preeclampsia, preterm delivery, low birth weight, increased fetal death and newborn's care time in neonatal care unit [5-7] Therefore, women should be given proper oral hygiene and oral health preventive services before, during and even after child birth [8].

Mother's oral health behavior during pregnancy, such as dental visits, oral hygiene, and consumption of sweets have a significant effect on their oral health during pregnancy and on their children's oral health in the future [9, 10]. Expectant women should be counseled to perform routine brushing and flossing, to avoid consuming excessive amounts of sugary snacks and drinks, and to consult a dentist during pregnancy [11].

Pregnant women may not be aware of the effects of their oral health on the fetus and their pregnancy outcomes [12]. Plenty of studies have shown pregnant women had negative attitude towards their oral health care and dental care utilization in pregnancy period [13, 14]. Patients and dentists usually avoid dental treatment during pregnancy because of absence of clinical guidelines for dental management in pregnancy, lack of practice standards, and anxiety about fetal safety during dental procedures [15].

Although oral health in pregnancy is an important issue in pregnancy health, few epidemiological studies have reported clinical oral health indices in the population. A search in PubMed database with Mesh keywords of "pregnant women" and "oral health" in May 2019 resulted in finding 34 papers, from which only four contained information regarding clinical oral health examination [16-19]. This shortage of literature may be because of neglected oral health as a part of needed maternal care and less dental visits in pregnancy.

Oral health of Iranian adults (aged 35-44) has been studied in a recent epidemiological study in 2012 [20]; however, it did not include pregnant women.

The aim of this study was to get baseline data about oral health status and dental care behaviors of pregnant women in Varamin, a partially deprived region in the southern part of Tehran Province, Iran.

This information may be helpful to design and plan interventions regarding oral health promotion among this target population.

\section{Methods}

This study was approved by the Committee of Ethics in Research Affairs of Dental School, Shahid Beheshti University of Medical sciences. After explanation of the study objectives, an informed consent was obtained for the participation. Women filled the consent form, and signed it for participation. There was a participant under
16 years whose consent form was signed by her father as her legal guardian according the local rules.

This community-based cross-sectional study was performed to provide the baseline data for a community oral health promoting intervention to be implemented in "Pishva";"Pakdasht", both regions located in Varamin, a southern part of Tehran Province in Iran. At the 2016 census, Pishva's population was 86,601 and Pakdasht was 350,966 (https://www.amar.org.ir/english/Populationand-Housing-Censuses). Pishva and Pakdasht are similar regions in terms of socioeconomic status. Data gathering started in July 2016, and lasted for eight months.

\section{Sample size and subject recruitment}

In this study in order to estimate the mean Decayed, Missed, Filled teeth (DMFT) in pregnant women, according to the previous study on decay-missing-filled (DMF) of Iranian pregnant women [21], the Standard Deviation (SD), was found to be 3 , considering $95 \%$ confidence with an error equal to 0.3 a sample of approximately 387 subjects was needed to be participated in the study.

The target population was pregnant women in the second/third trimester of pregnancy living in Varamin. Women with known systemic disease, with high-risk pregnancy, age under 15 years, and on long-term medication were excluded. Recruitment was carried out in all the 17 health care centers in Pishva (7 health care centers) and Pakdasht (10 health care centers), where more than $70 \%$ of pregnant women residing in those regions usually receive their maternal care from these public health centers. All of the health care centers provided free maternal and child care for their target groups at the same conditions. All 407 pregnant women in their second/third trimester of pregnancy who received prenatal care from the health centers were recalled toparticipate in the study.

\section{Study design}

Two dentists were trained according to the World Health Organization (WHO) oral health surveys basic methods (15), and were calibrated clinically using $10 \mathrm{pa}-$ tients in a two-day calibration workshop. The intra- and inter-examiner reliability of measuring dental caries and pocket depth were investigated for both examiners. The mean inter-examiner agreement obtained in this activity was Kappa $=0.85$. Dental and periodontal examinations were taken in in maternity care room of Pishva and Pakdasht health centers on an ordinary seat.. Teeth were dried by cotton rolls, and oral examination was performed using battery-operated lights, mouth mirror, and community periodontal index probe according to the recommendations of WHO [22].

For assessing periodontal status, BOP and periodontal pocket were detected. Gingivae of all teeth present in 
participants' mouth examined by inserting the tip of the WHO CPI probe between the gingiva and the tooth to assess absence or presence of bleeding response. All participant's teeth present in the mouth were examined for absence or presence of gingival.

bleeding and absence or presence of periodontal pockets; pocket depth is measured with the WHO CPI periodontal probe. The probe tip inserted gently into six sites of the gingival sulcus or pocket and the full extent of the sulcus or pocket explored.

After oral examination and interview, all the study participants were given a tube of fluoridated tooth paste and a tooth brush. The brushing was demonstrated to all and were advised to brush twice a day.

\section{Variables}

Outcome variables collected through oral examination included DMFT, bleeding on probing at least one site, and having periodontal pocket $>3.5 \mathrm{~mm}$ in at least one tooth.

Explanatory variables were collected via face to face interviews using a structured standard questionnaire. The questionnaire included information regarding the explanatory variables including pregnant women's age, trimester of pregnancy (second/third), educational background, job, frequency of tooth brushing/ dental flossing/ sweets consumption, dental visit, and cause of last dental visit.

Women's education was asked with 5 possible answers from "illiterate" to "university degrees" which was then classified to "Less than 12 years", "12 years", and "More than12 years" for further analysis. The responses for brushing/flossing/sweet consumption were dichotomized into "once a day or more" or "less than once a day". Dental visit information was gathered through a yes/no question: "Have you had any dental visits in the previous 12 months?" the cause of the last dental visit was asked and dichotomized into treatment and checkup (consultation, checkup). Mother's job was asked with 2 possible answers from "house keeper" to "employed".

\section{Statistical analysis}

All the data were entered in a data entry form and statistical analysis was performed using SPSS version 21 and STATA/SE 11. For bivariate statistical analysis, Independent Sample T-test, Chi-square, one-way ANOVA and Mann-Whitney $U$ tests were used. For modeling DMFT, D, and M, negative binomial models were used, and for BOP and periodontal pocket, binary logistic regressions were applied. Because of plenty of zeros in F, zero-inflated negative binomial model was used. Unadjusted and adjusted models were used to study the association between explanatory variables and outcome variables, considering $P$-value less than 0.05 as statistically significant level. Model 1 included age group. Model 2 consisted of age group, and trimester of pregnancy. Education was added to Model 3 while oral health behaviors (brushing habit, flossing habit, dental visit and sweet consumption) were added to Model 4 .

\section{Results}

From the 532 registered women, 451 attended the examination session. Also, 38 pregnant women (in Pishva) and 43 pregnant mothers (in Pakdasht) did not attend the examination exactly. The flowchart of study design is provided in Fig. 1. The mean age (SD) of the 407 pregnant women was 27.35(5.57). Approximately, half of the participants were $25-35$ years old, ranging between 15 to 44 years. A majority of the expectant women (59.7\%) were in second trimester of pregnancy. Approximately, half of the women were educated less than 12 years. Only $1.7 \%$ of women were employed. The frequency of daily brushing among participated women was $64.1 \%$ and One out of four women had daily flossing habit (Table 1).

The mean (SD) DMFT, D, M and F in our study participant group were 10.34(5.10), 6.94(4.40), 2.22 (2.68) and 1.19(2.23), respectively. Dental decay accounted for approximately $67 \%$ of DMFT while dental filling accounted for only $10 \%$.

The percentage of D/DMFT in 15-25 years age group was $78 \%$ and in $35-44$ years age was $44 \%$, while percentage of M/DMFT in 15-25 years and 35-44 years age group were 14 and $44 \%$, respectively. The contribution of filling teeth among DMFT was low in all age groups. Women in third trimester of pregnancy had significantly more periodontal pocket $>3.5 \mathrm{~mm}$, compared to women in second trimester $(p<0.05)$.

Approximately three quarters of participants had BOP while $27 \%$ had periodontal pocket $>3.5 \mathrm{~mm}$. Among those having periodontal pocket, the mean (SD) of total number of teeth with periodontal pocket $>3.5 \mathrm{~mm}$ was 3.9 (4.47).

As reported in Table 1, less dental caries and more dental fillings were observed among pregnant women with more than 12 years education $(p<0.01)$. Bleeding on probing and having periodontal pocket more than $3.5 \mathrm{~mm}$ were significantly more in women using dental floss less than once a day $(\mathrm{p}<0.05)$. Expectant mothers who had dental visit in the previous years had significantly more filled and missed teeth $(\mathrm{p}<0.01)$. More missing teeth were observed in participants who had visited a dentist to get a treatment $(\mathrm{p}<0.01)$.

Women older than 35 years had 1.3 times more DMFT $[C R=1.35$ (95\% CI 1.13; 1.60)] (Table 2), 0.25 times less decayed teeth $[\mathrm{CR}=0.75$ (95\% CI 0.59; 0.94)] (Table 3), and 3.5 times more missing teeth $[\mathrm{CR}=3.63$ (95\% CI 2.57; 5.14)] compared to women younger than 25 (Table 4).

Also, women who haven't visited a dentist in the previous years had significantly less DMFT $[\mathrm{CR}=0.86(95 \%$ CI $0.77 ; 0.95)]$. Having more than 12 years education was associated with less dental caries, even after 


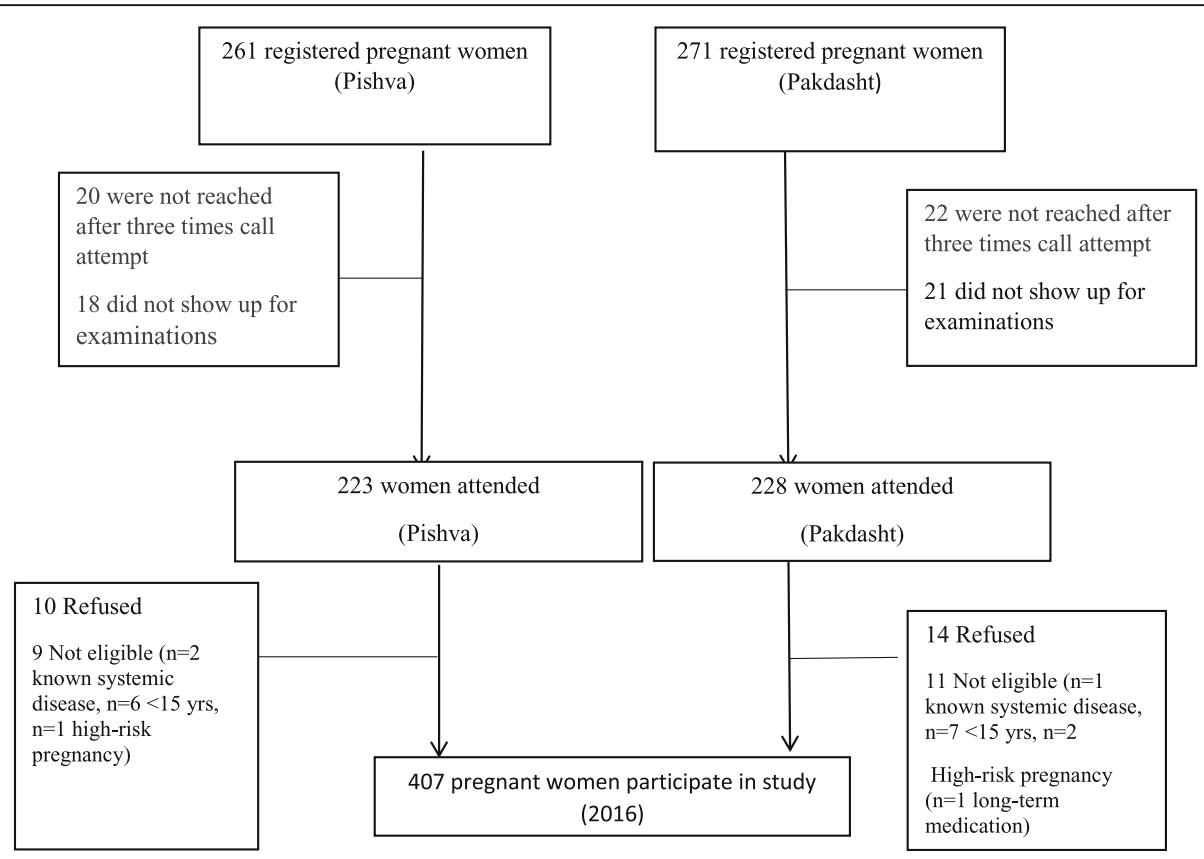

Fig. 1 Flowchart of study design

controlling for dental care behaviors [CR $=0.63$ (95\% CI $0.48 ; 0.84)]$. Also, women who had brushed their teeth less than once a day had significantly more decayed teeth $[\mathrm{CR}=1.15$ (95\% CI 1.00; 1.31)].

Additionally, women who haven't visited a dentist in the previous year had significantly less dental missing $[\mathrm{CR}=0.75(95 \%$ CI $0.61 ; 0.93)]$.

Tables 5 illustrates that filling teeth increased by age but after controlling for dental care behaviors, this association was not significant any more.

Regression analysis for BOP reveal that sweet consumption more than once a day and flossing less than once a day were positively related to BOP. The detailed table is provided in the appendix 1.

\section{Discussion}

The finding of the present study showed the high prevalence of gingival diseases and dental caries in pregnant women. Having a mean of seven decayed teeth in mother's mouth, can be a prelude to dental caries in newborns' mouth via bacterial transmission. The mean DMFT was 10.34 which was higher than the mean DMFT of pregnant women in Arak and Shiraz, two major cities in Iran [21, 23]. Differences in the DMFT in different areas of Iran may be due to the differences in socioeconomic status of the studied regions. The Iranian National Oral Health Survey-2012 did not include pregnant women. According the results of this study, the mean DMFT in 35-44 years old females was 13.07 [20], being similar to this age group DMFT in the present study.
Dental decay accounted for $67 \%$ of DMFT while dental filling accounted for only $10 \%$ of DMFT, showing that most of dental caries have been left untreated. In older age groups, the percentage of $\mathrm{D}$ was lower, and the percentage of missing teeth were higher than the younger age groups. It indicates inappropriate use of dental services, leading to extraction of decayed teeth rather to reserve them by dental treatment. The private-dominant dental care system, financial barriers, and insufficient accessibility of dental care may be the underlying causes [24, 25].

This high proportion of D to DMFT is also in agreement with studies on pregnant women in developing countries like India [26], and rural Sri Lanka [17]. But it was in contrast with a study from Australia [27], where $\mathrm{F}$ was the largest portion of DMFT. This may be because of the differences in socioeconomic status, oral health beliefs, access to dental care and patterns of dental care utilization between developed and developing countries.

In the present study, there was a significant positive association between age and DMFT $(p<0.001)$, which is comparable to another study done on pregnant women in Iran [21], and a study from India, where decayed teeth were influenced by age [28].

In this study more than half of the participants (64.1\%) reported that they brushed their teeth once a day or more, which was far less than the pregnant women daily brushing frequency in Finland (90\%), Australia (91\%), Kuwait (92\%), and England (73.7\%) [27, 29-31]. Brushing habit in pregnancy is affected by nausea during pregnancy which may lead to decreased frequency of habit in this stage. However, it 


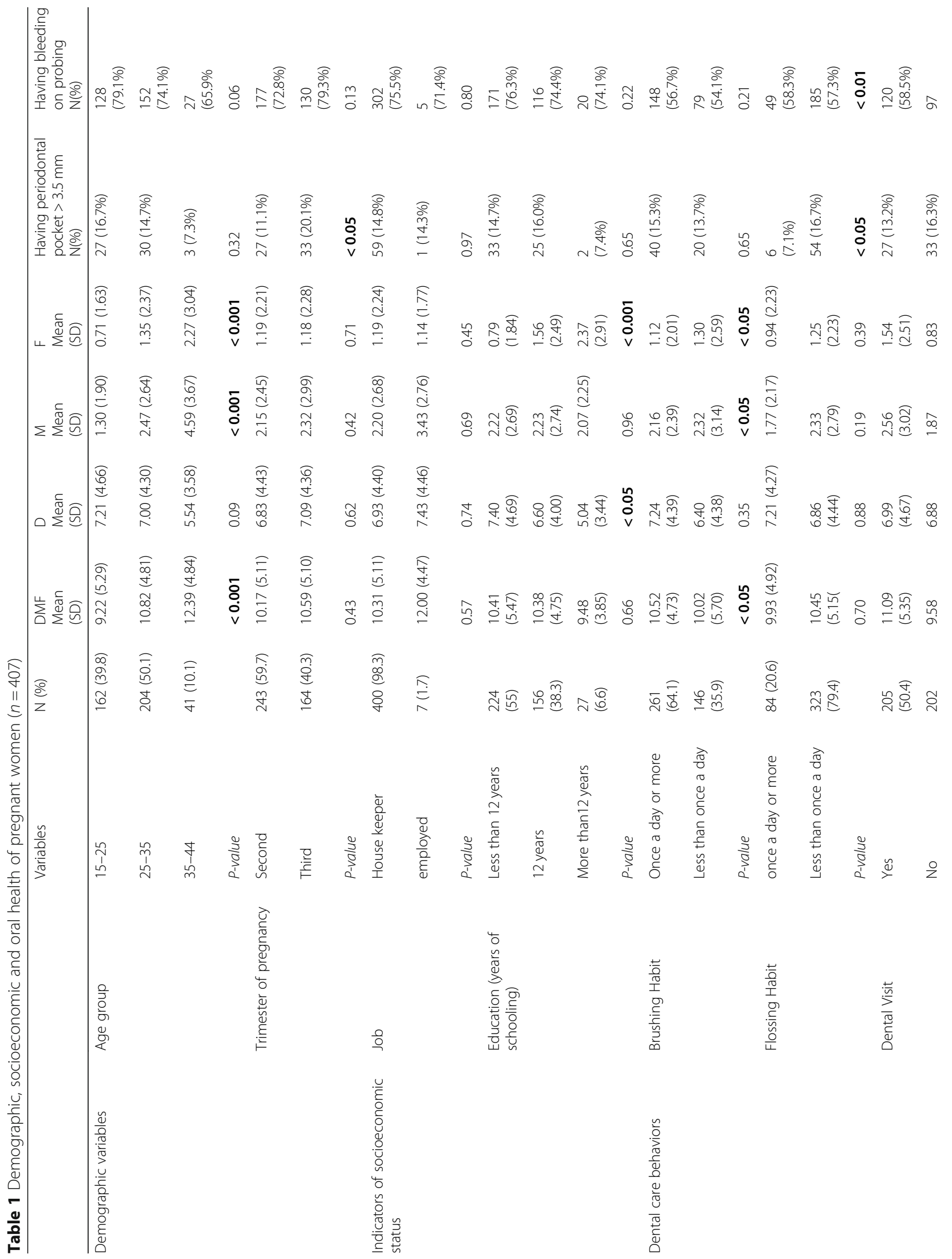




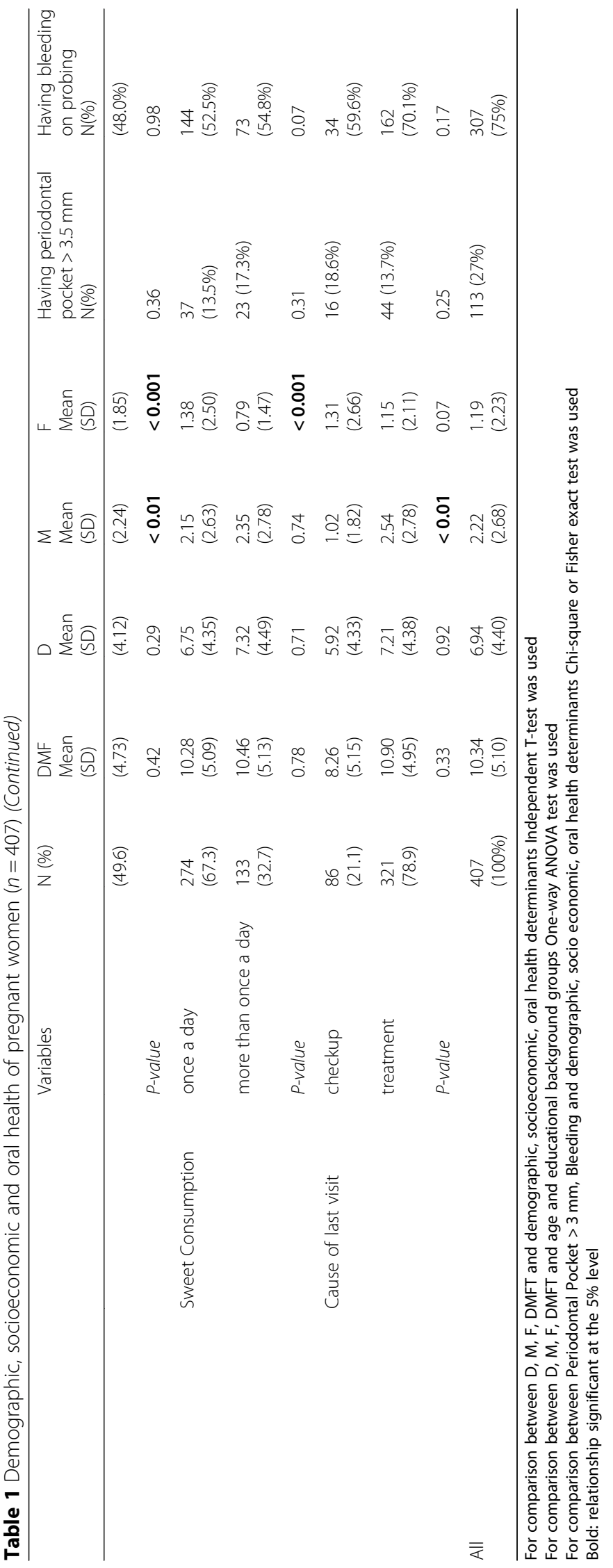


Table 2 Association between demographic and dental care behaviors with number of DMFT

\begin{tabular}{|c|c|c|c|c|c|}
\hline \multirow[t]{2}{*}{ Variables } & & \multirow{2}{*}{$\begin{array}{l}\text { Model } 1 \\
\text { CR(95\%Cl) }\end{array}$} & \multirow{2}{*}{$\begin{array}{l}\text { Model } 2 \\
\text { CR(95\%Cl) }\end{array}$} & \multirow{2}{*}{$\begin{array}{l}\text { Model } 3 \\
\text { CR(95\%Cl) }\end{array}$} & \multirow{2}{*}{$\begin{array}{l}\text { Model } 4 \\
\text { CR(95\%Cl) }\end{array}$} \\
\hline & & & & & \\
\hline Age & $\begin{array}{l}15-25 \\
25-35 \\
35-45\end{array}$ & $\begin{array}{l}1 \\
1.15(1.03 ; 1.29) \\
1.32(1.12 ; 1.1 .59)\end{array}$ & $\begin{array}{l}1 \\
1.17(1.05 ; 1.30) \\
1.34(1.13 ; 1.60)\end{array}$ & $\begin{array}{l}1 \\
1.17(1.05 ; 1.31) \\
1.34(1.13 ; 1.60)\end{array}$ & $\begin{array}{l}1 \\
1.18(1.06 ; 1.31) \\
1.35(1.13 ; 1.60)\end{array}$ \\
\hline Trimester & $\begin{array}{l}\text { Second } \\
\text { Third }\end{array}$ & & $\begin{array}{l}1 \\
1.04(0.94 ; 1.16)\end{array}$ & $\begin{array}{l}1 \\
1.04(0.94 ; 1.15)\end{array}$ & $\begin{array}{l}1 \\
1.04(0.94 ; 1.15)\end{array}$ \\
\hline Education & $\begin{array}{l}\text { Less than } 12 \text { years } 12 \text { years } \\
\text { More than } 12 \text { years }\end{array}$ & & & $\begin{array}{l}1 \\
0.99(0.89 ; 1.10) \\
0.92(0.74 ; 1.13)\end{array}$ & $\begin{array}{l}1 \\
0.97(0.87 ; 1.08) \\
0.89(0.72 ; 1.10)\end{array}$ \\
\hline Brushing Habit & $\begin{array}{l}\text { once a day } \\
\text { Less than once a day }\end{array}$ & & & & $\begin{array}{l}1 \\
1.04(0.94 ; 1.16)\end{array}$ \\
\hline Flossing Habit & $\begin{array}{l}\text { Less than once } \\
\text { Once a day or more }\end{array}$ & & & & $\begin{array}{l}1 \\
0.95(0.84 ; 1.08)\end{array}$ \\
\hline Dental Visit & $\begin{array}{l}\text { Yes } \\
\text { No }\end{array}$ & & & & $\begin{array}{l}1 \\
0.86(0.77 ; 0.95)\end{array}$ \\
\hline Sweet Consumption & $\begin{array}{l}\text { Once } \\
\text { More than once }\end{array}$ & & & & $\begin{array}{l}1 \\
1.02(0.92 ; 1.14)\end{array}$ \\
\hline
\end{tabular}

Negative binomial regression

Bold: relationship significant at the $5 \%$ level

Model 1: adjusted for age group

Model 2: adjusted for age group, trimester of pregnancy

Model 3: adjusted for age group, trimester of pregnancy, education

Model 4 adjusted for age group, trimester of pregnancy, education, oral health behaviors

is very crucial because pregnant women who do not care enough to brush their own teeth will probably neglect cleaning their baby's mouth [32, 33].

We found that higher education was associated with less dental caries. Our result confirmed the findings from previous studies from Iran $[21,34]$ and other countries [35-37] in which women with low level of education were more likely to have untreated dental caries compared to women with high level of education.

In our study, $67.3 \%$ of pregnant women consumed sweets once a day. A study on a group of Asian women living in England showed that about 63\% of pregnant

Table 3 Association between demographic and dental care behaviors with number of decayed teeth

\begin{tabular}{|c|c|c|c|c|c|}
\hline Variables & & $\begin{array}{l}\text { Model } 1 \\
\text { CR }(95 \% \mathrm{Cl})\end{array}$ & $\begin{array}{l}\text { Model } 2 \\
\text { CR }(95 \% \mathrm{Cl})\end{array}$ & $\begin{array}{l}\text { Model } 3 \\
\text { CR }(95 \% \mathrm{Cl})\end{array}$ & $\begin{array}{l}\text { Model } 4 \\
\text { CR }(95 \% \mathrm{Cl})\end{array}$ \\
\hline Age & $\begin{array}{l}15-25 \\
25-35 \\
35-45\end{array}$ & $\begin{array}{l}1 \\
0.97(0.84 ; 1.11) \\
\mathbf{0 . 7 6 ( 0 . 6 0 ; 0 . 9 7 )}\end{array}$ & $\begin{array}{l}1 \\
0.97(0.85 ; 1.11) \\
\mathbf{0 . 7 7}(\mathbf{0 . 6 0} ; \mathbf{0 . 9 8 )}\end{array}$ & $\begin{array}{l}1 \\
0.98(0.86 ; 1.13) \\
\mathbf{0 . 7 5}(\mathbf{0 . 5 9} ; \mathbf{0 . 9 4 )}\end{array}$ & $\begin{array}{l}1 \\
0.98(0.86 ; 1.13) \\
\mathbf{0 . 7 5}(\mathbf{0 . 5 9 ; 0 . 9 4 )}\end{array}$ \\
\hline Trimester & $\begin{array}{l}\text { Second } \\
\text { Third }\end{array}$ & & $\begin{array}{l}1 \\
1.03(0.90 ; 1.18)\end{array}$ & $\begin{array}{l}1 \\
1.01(0.88 ; 1.15)\end{array}$ & $\begin{array}{l}1 \\
1.00(0.88 ; 1.14)\end{array}$ \\
\hline Education & $\begin{array}{l}\text { Less than } 12 \text { years } \\
12 \text { years } \\
\text { More than } 12 \text { years }\end{array}$ & & & $\begin{array}{l}1 \\
0.87(0.76 ; 1.00) \\
\mathbf{0 . 6 6 ( 0 . 5 0 ; 0 . 8 8 )}\end{array}$ & $\begin{array}{l}1 \\
0.86(0.75 ; 0.99) \\
0.63(0.48 ; 0.84)\end{array}$ \\
\hline Brushing habit & $\begin{array}{l}\text { once a day } \\
\text { Less than once a day }\end{array}$ & & & & $1.15(1.00 ; 1.31)$ \\
\hline Flossing habit & $\begin{array}{l}\text { Less than once } \\
\text { Once a day or more }\end{array}$ & & & & $\begin{array}{l}1 \\
1.10(0.94 ; 1.29)\end{array}$ \\
\hline Dental visit & $\begin{array}{l}\text { Yes } \\
\text { No }\end{array}$ & & & & $\begin{array}{l}1 \\
0.96(0.84 ; 1.09)\end{array}$ \\
\hline Sweet Consumption & $\begin{array}{l}\text { Once } \\
\text { More than once }\end{array}$ & & & & $\begin{array}{l}1 \\
1.05(0.92 ; 1.21)\end{array}$ \\
\hline
\end{tabular}

Negative binomial regression

$\mathrm{CR}$, count ratio; $\mathrm{Cl}, 95 \%$ confidence interval

Bold: relationship significant at the $5 \%$ level

Model 1: adjusted for age group

Model 2: adjusted for age group, trimester of pregnancy

Model 3: adjusted for age group, trimester of pregnancy, education

Model 4 adjusted for age group, trimester of pregnancy, education, oral health behaviors 
Table 4 Association between demographic and dental care behaviors with number of missing teeth

\begin{tabular}{|c|c|c|c|c|c|}
\hline Variables & Levels & $\begin{array}{l}\text { Model } 1 \\
\text { CR(95\%Cl) }\end{array}$ & $\begin{array}{l}\text { Model } 2 \\
\text { CR(95\%Cl) }\end{array}$ & $\begin{array}{l}\text { Model } 3 \\
\text { CR(95\%Cl) }\end{array}$ & $\begin{array}{l}\text { Model } 4 \\
\text { CR(95\%Cl) }\end{array}$ \\
\hline Age & $\begin{array}{l}15-25 \\
25-35 \\
35-45\end{array}$ & $\begin{array}{l}1 \\
1.90(1.50 ; 2.41) \\
3.53(2.49 ; 5.02)\end{array}$ & $\begin{array}{l}1 \\
1.90(1.50 ; 2.41) \\
3.59(2.53 ; 5.10)\end{array}$ & $\begin{array}{l}1 \\
1.90(1.49 ; 2.41) \\
3.59(2.53 ; 5.11)\end{array}$ & $\begin{array}{l}1 \\
1.96(1.55 ; 2.49) \\
3.63(2.57 ; 5.14)\end{array}$ \\
\hline Trimester & $\begin{array}{l}\text { Second } \\
\text { Third }\end{array}$ & & $\begin{array}{l}1 \\
1.13(0.91 ; 1.41)\end{array}$ & $\begin{array}{l}1 \\
1.13(0.91 ; 1.41)\end{array}$ & $\begin{array}{l}1 \\
1.10(0.89 ; 1.37)\end{array}$ \\
\hline Education & $\begin{array}{l}\text { Less than } 12 \text { years } \\
12 \text { years } \\
\text { More than } 12 \text { years }\end{array}$ & & & $\begin{array}{l}1 \\
1.01(0.80 ; 1.26) \\
1.02(0.65 ; 1.59)\end{array}$ & $\begin{array}{l}1 \\
0.98(0.79 ; 1.23) \\
1.02(0.65 ; 1.59)\end{array}$ \\
\hline Brushing Habit & $\begin{array}{l}\text { Once a day } \\
\text { Less than Once a day }\end{array}$ & & & & $\begin{array}{l}1 \\
0.90(0.72 ; 1.12)\end{array}$ \\
\hline Flossing Habit & $\begin{array}{l}\text { Less than Once a day } \\
\text { Once a day or more }\end{array}$ & & & & $\begin{array}{l}1 \\
0.75(0.57 ; 0.99)\end{array}$ \\
\hline Dental Visit & $\begin{array}{l}\text { Yes } \\
\text { No }\end{array}$ & & & & $\begin{array}{l}1 \\
0.75(0.61 ; 0.93)\end{array}$ \\
\hline Sweet Consumption & $\begin{array}{l}\text { Once } \\
\text { More than once }\end{array}$ & & & & $1.15(0.92 ; 1.44)$ \\
\hline
\end{tabular}

Negative binomial regression

$\mathrm{CR}$, count ratio; $\mathrm{Cl}, 95 \%$ confidence interval

Bold: relationship significant at the $5 \%$ level

Model 1: adjusted for age group

Model 2: adjusted for age group, trimester of pregnancy

Model 3: adjusted for age group, trimester of pregnancy, education

Model 4 adjusted for age group, trimester of pregnancy, education, oral health behaviors

women during pregnancy increased consumption of sugar [38]. Women who consumed sweets more than once a day had significantly less dental fillings. This could be explained by possible clustering of dental care behaviors like more sweet consumption and less frequent dental visits documented elsewhere [12]. This finding is in accordance with previous evidence suggesting more number of filling in older expectant mothers who consume more sweets $[38,39]$. Both sweet consumption and dental visit behaviors are usually affected by pregnancy. Pregnant women tend to use more sweets and avoid dental visit.

Table 5 Association between demographic and dental care behaviors with number of filling teeth

\begin{tabular}{|c|c|c|c|c|c|}
\hline Variables & Levels & $\begin{array}{l}\text { Model } 1 \\
\text { CR( }(95 \% \mathrm{Cl})\end{array}$ & $\begin{array}{l}\text { Model } 2 \\
\text { CR( } 95 \% \mathrm{Cl})\end{array}$ & $\begin{array}{l}\text { Model } 3 \\
\text { CR( }(95 \% \mathrm{Cl})\end{array}$ & $\begin{array}{l}\text { Model } 4 \\
\text { CR( }(95 \% \mathrm{Cl})\end{array}$ \\
\hline Age & $\begin{array}{l}15-25 \\
25-35 \\
35-45\end{array}$ & $\begin{array}{l}1 \\
1.40(0.89 ; 2.21) \\
\mathbf{2 . 1 2}(\mathbf{1 . 1 4} ; \mathbf{3 . 9 2})\end{array}$ & $\begin{array}{l}1 \\
1.35(0.84 ; 2.15) \\
\mathbf{2 . 0 9}(\mathbf{1 . 1 3 ; 3 . 8 8 )}\end{array}$ & $\begin{array}{l}1 \\
1.13(0.71 ; 1.79) \\
\mathbf{2 . 0 3 ( 1 . 0 9 ; 3 . 7 9 )}\end{array}$ & $\begin{array}{l}1 \\
1.06(0.62 ; 1.81) \\
1.69(0.92 ; 3.12)\end{array}$ \\
\hline Trimester & $\begin{array}{l}\text { Second } \\
\text { Third }\end{array}$ & & $\begin{array}{l}1 \\
1.14(0.75 ; 1.72)\end{array}$ & $\begin{array}{l}1 \\
1.26(0.82 ; 1.93)\end{array}$ & $\begin{array}{l}1 \\
1.02(0.65 ; 1.61)\end{array}$ \\
\hline Education & $\begin{array}{l}\text { Less than } 12 \text { years } \\
12 \text { years } \\
\text { More than } 12 \text { years }\end{array}$ & & & $\begin{array}{l}1 \\
1.25(0.81 ; 1.92) \\
1.44(0.77 ; 2.70)\end{array}$ & $\begin{array}{l}1 \\
1.27(0.82 ; 1.97) \\
1.43(0.79 ; 2.59)\end{array}$ \\
\hline Brushing Habit & $\begin{array}{l}\text { Once a day } \\
\text { Less than Once a day }\end{array}$ & & & & $\begin{array}{l}1 \\
0.75(0.47 ; 1.19)\end{array}$ \\
\hline Flossing Habit & $\begin{array}{l}\text { Less than Once a day } \\
\text { Once a day or more }\end{array}$ & & & & $\begin{array}{l}1 \\
1.34(0.78 ; 2.32)\end{array}$ \\
\hline Dental Visit & $\begin{array}{l}\text { Yes } \\
\text { No }\end{array}$ & & & & $\begin{array}{l}1 \\
0.81(0.54 ; 1.22)\end{array}$ \\
\hline Sweet Consumption & $\begin{array}{l}\text { Once } \\
\text { More than once }\end{array}$ & & & & $\begin{array}{l}1 \\
0.60(0.37 ; 0.99)\end{array}$ \\
\hline
\end{tabular}

Zero inflated negative binomial regression

$\mathrm{CR}$, count ratio; $\mathrm{Cl}, 95 \%$ confidence interval

Bold: relationship significant at the $5 \%$ level

Model 1: adjusted for age group

Model 2: adjusted for age group, trimester of pregnancy

Model 3: adjusted for age group, trimester of pregnancy, education

Model 4 adjusted for age group, trimester of pregnancy, education, dental care behaviors 
It was observed here that half of the studied pregnant women did not visit a dentist in the previous year, and those without dental visit had significantly less dental missing. This finding could be because of the role of dentist in teeth extraction; people should visit a dentist to remove their teeth. Similar to our findings, the American study reported that $35 \%$ of pregnant women who did not have a dental visit within the past year and $56 \%$ of women did not visit a dentist during pregnancy [40]. Studies reported that pregnant women experienced oral health problems and they did not often utilize dental care services during pregnancy [41, 42]. Many pregnant women believe that dental procedures are harmful for them and their fetuses [43]. In spite of highly subsidized dental care services for pregnant women in Iran public health care centers, pregnant women had less dental visits. It indicates the need for changing the attitude of expectant mothers in this regard.

BOP is an indicator of poor oral hygiene, and is of special importance in pregnancy, when inflammatory response to gingival bacteria is elevated [44-46]. Both BOP and periodontal pockets have been shown to affect pregnancy outcomes including increasing the chance of low birth weight and preterm birth [46].

This study was one of the few epidemiological studies on pregnant women in Iran. It benefited from good sample size from all health care centers of Pishva and Pakdasht including. The results of this study cannot be generalized to all Iranian pregnant women; however, it covers a representative sample in Varamin region.

However, some limitations should be considered in the current study. Some pregnant women did not show up for examinations although they were contacted up to three times. The researchers tried to encourage women for participation by providing free toothbrush and toothpastes. There were some oral health behaviors like using mouth rinse which were not studied in this research. We could not find any published evidence regarding the prevalence of mouth rinse use in Iran which informal references report it to be very low in Iranian population.

The other limitation of study was the cross-sectional design which did not allow us to study the chronological order of the risk factors and outcomes, not permitting study the causation, effect.

This study provides a snapshot of oral health status of pregnant women in a partially deprived area in Iran. The findings showed that a majority of expectant mothers had gingival inflammation, having a mean of seven decayed teeth in their mouth. This situation indicates high level of unfavorable bacteria in mothers' mouth which will be transferrable to the newborns' mouth in the future. The authors suggestions regarding these study findings are: 1 - before pregnancy, women should be clinically examined and advised to get necessary dental treatments. It could be emphasized by midwives and gynecologists who are involved in maternity health. 2- during pregnancy, women's oral hygiene education should be integrated in the common maternal care. It could be also of important step for the mothers to take the responsibility of oral health of their newborns.

\section{Conclusion}

Oral health status of pregnant women was not satisfactory, having an average of seven decayed teeth in their mouth. Older women had less dental caries but apparently more missing teeth indicating improper received dental care.

\section{Abbreviations}

BOP: Bleeding On Probing; Cl: Confidence Intervals; CR: Count Ratios; DMFT: Decayed, Missed, Filled Teeth; SD: Standard Deviation; WHO: World Health Organization

\section{Acknowledgements}

The authors have no conflict of interest to report. The authors wish to acknowledge Dr. Rahmanali Taheri, Dr. Shahzadeh Fazeli, Dr. Parvin Bastani from Deputy for health affairs, Shahid Beheshti University of Medical Sciences for their kind help and support for this study. Thanks to Dr. Gholami, Mrs. Kooshmaghani) Pishva health network) and Dr. Fathi, Mrs.Mozayeni (Pakdasht health network) and all of primary care providers who work in Pishva and Pakdasht health centers for their diligent work during the clinical field work.

\section{Authors' contributions}

Conception and design of study/review/case series: MD, ZG, SA, FE. Acquisition of data: MD, ZG, SG, SA, FE. Analysis of collected data: MD, ZG, MN, MP. Interpretation of data: ZG, SG, SA, FE, MP. Drafting of paper and/or critical revision: MD, ZG, SG, SA, FE, MN, MP. All the authors have read and approved the manuscript to be submitted to BMC Oral Health.

\section{Funding}

This study was funded by Research Affairs of Dental School, Shahid Beheshti University of Medical Sciences, Tehran, Iran.

\section{Availability of data and materials}

The data that support the findings of this study are available from the corresponding author upon reasonable request.

\section{Ethics approval and consent to participate}

This study was approved by the Committee of Ethics in Research Affairs of Dental School, Shahid Beheshti University of Medical sciences. Some participants were illiterate, and it was not possible to get written consent from all people. After explanation of the study objectives, verbal informed consent was obtained for the participation. The Ethical Committee agreed with verbal consent acquisition.

\section{Consent for publication}

Not applicable.

\section{Competing interests}

The authors declare that they have no competing interests.

\section{Author details}

${ }^{1}$ Dental Research Center, Research Institute of Dental Sciences, Dental School, Shahid Beheshti University of Medical Sciences, Tehran, Iran.

${ }^{2}$ Community Oral Health Department, School of Dentistry, Shahid Beheshti University of Medical Sciences, Daneshjoo Blvd, Tehran, IR 19834, Iran. ${ }^{3}$ Department of Health Education and Health Promotion, Deputy for Health affairs, Shahid Beheshti University of Medical sciences, Tehran, Iran. ${ }^{4}$ Deputy for Health affairs, Shahid Beheshti University of Medical Sciences, Tehran, Iran. ${ }^{5}$ Obstetrician and gynecologist, Deputy of Health Affairs, Shahid Beheshti University of Medical Sciences, Tehran, Iran. ${ }^{6}$ Of Biostatistics, Department Of 
Community Oral Health, School Of Dentistry, Shahid Beheshti University Of Medical Sciences, Tehran, Iran. 'Community Oral Health Department, Schoo of Dentistry, Golestan University of Medical Sciences, Gorgan, Iran.

Received: 20 November 2018 Accepted: 31 May 2019

Published online: 17 June 2019

\section{References}

1. Pirie M, Cooke I, Linden G, et al. Dental manifestations of pregnancy. Obstet Gynecol. 2007;9:21-6.

2. Mills LW, Moses DT. Oral health during pregnancy. MCN Am J Matern Child Nurs. 2002;27:275-80.

3. Shanthi V, Vanka A, Bhambal A, et al. Association of pregnant women periodontal status to preterm and low-birth weight babies: A systematic and evidence-based review. Dent Res J. 2012;9:368-80.

4. Marla V, Srii R, Roy DK, et al. The Importance of Oral Health during Pregnancy: A review. MedicalExpress. 2018;5:1-6.

5. Ha JE, Jun JK, Ko HJ, et al. Association between periodontitis and preeclampsia in never-smokers: a prospective study. J. Clin. Periodontol. 2014;41:869-74.

6. Iheozor-Ejiofor Z, Middleton P, Esposito M, et al. Treating periodontal disease for preventing adverse birth outcomes in pregnant women. Cochrane Database Syst Rev. 2017. https://doi.org/10.1002/14651858.

7. Mohebbi SZ, Virtanen II, Murtomaa H, et al. Mothers as facilitators of oral hygiene in early childhood. Int J Paediatr Dent. 2008;18:48-55.

8. Corbella S, Taschieri S, Del Fabbro M, et al. Adverse pregnancy outcomes and periodontitis: A systematic review and meta-analysis exploring potential association. Quintessence Int. 2016;47:193-204.

9. Marinho VC, Higgins J, Logan S, et al. Fluoride toothpastes for preventing dental caries in children and adolescents. Cochrane Database Syst Rev. 2003. https://doi.org/10.1002/14651858.

10. Adair PM, Pine CM, Burnside G, et al. Familial and cultural perceptions and beliefs of oral hygiene and dietary practices among ethnically and socioeconomicall diverse groups. CDH. 2004;21:102-11.

11. Silk H, Douglass AB, Douglass JM et al. Oral health during pregnancy. Am Fam Physician.2008;77:1139-1144

12. Abati S, Villa A, Cetin I, et al. American Academy of Periodontology statement regarding periodontal management of the pregnant patient. J Periodontol. 2004;75:495

13. Bates SB, Riedy CA. Changing knowledge and beliefs through an oral health pregnancy message. J Public Health Dent. 2012;72:104-11.

14. Martínez-Beneyto Y, Vera-Delgado MV, Pérez L, et al. Self-reported oral health and hygiene habits, dental decay, and periodontal condition among pregnant European women. Int J Gynaecol Obstet. 2011;114:18-22.

15. Kandan PM, Menaga $V$, Kumar RRR. Oral health in pregnancy (quidelines to gynaecologists, general physicians \& oral health care providers). J Pak Med Assoc. 2011:61:1009.

16. Chawla R, Shetiya S, Agarwal D, et al. Knowledge, Attitude, and Practice of Pregnant Women regarding Oral Health Status and Treatment Needs following Oral Health Education in Pune District of Maharashtra: A Longitudinal Hospital-based Study. J Contemp Dent Pract. 2017:18:371-7.

17. Karunachandra N, Perera I, Fernando G. Oral health status during pregnancy: rural--urban comparisons of oral disease burden among antenatal women in Sri Lanka. Rural Remote Health. 2012;12:1902.

18. Wandera M, Åstrøm AN, Okullo I, et al. Determinants of periodontal health in pregnant women and association with infants' anthropometric status: a prospective cohort study from Eastern Uganda. BMC Pregnancy Childbirth. 2012;12:90.

19. lida H, Kumar J, Radigan A. Oral health during perinatal period in New York State. Evaluation of 2005 Pregnancy Risk Assessment Monitoring System data. N Y State Dent J. 2009:75:43-7.

20. Khoshnevisan M, Ghasemianpour M, Samadzadeh H, et al. Oral health status and healthcare system in IR Iran. J. contemp. Med. Sci. 2018;4:107-18.

21. Shamsi M, Hidarnia A, Niknami S, et al. The status of dental caries and some acting factors in a sample of Iranian women with pregnancy. World J Med Sci. 2013;9:190-7.

22. Organization WHO. Oral health surveys: basic methods. 5th ed. World Health Organization; 2013.

23. Shaghaghian S, Malekmakan L, Rahimian V, et al. Dental caries status and its associated factors in pregnant women, Shiraz, Iran, 2014. J Oral Health Oral Epidemiol. 2017:6:165-72.

24. Marchi KS, Fisher-Owens SA, Weintraub JA, et al. Most pregnant women in California do not receive dental care: findings from a population-based study. Public Health Rep. 2010;125:831-42.
25. Jadidfard M-P, Yazdani S, Khoshnevisan M-H. Social insurance for dental care in Iran: a developing scheme for a developing country. Oral Health Dent Manag. 2012;11:189-98.

26. Gupta R, Acharya AK Oral health status and treatment needs among pregnant women of Raichur District, India: A population based cross-sectional study. Scientifica (Cairo). 2016. https:/doi.org/10.1155/2016/9860387.

27. Thomas NJ, Middleton PF, Crowther CA. Oral and dental health care practices in pregnant women in Australia: a postnatal survey. BMC pregnancy childbirth. 2008;8. https://doi.org/10.1186/1471-2393-8-13.

28. Kumar S, Tadakamadla J, Tibdewal $\mathrm{H}$, et al. Factors influencing caries status and treatment needs among pregnant women attending a maternity hospital in Udaipur city. India. J Clin Exp Dent. 2013;5:72-6.

29. Gürsoy M, Pajukanta R, Sorsa T, et al. Clinical changes in periodontium during pregnancy and post-partum. J Clin Periodontol. 2008;35:576-83.

30. Honkala S, Al-Ansari J. Self-reported oral health, oral hygiene habits, and dental attendance of pregnant women in Kuwait. J Clin Periodontol. 2005:32:809-14.

31. Hullah E, Turok Y, Nauta M, et al. Self-reported oral hygiene habits, dental attendance and attitudes to dentistry during pregnancy in a sample of immigrant women in North London. Arch Gynecol Obstet. 2008;277:405-9.

32. Azimi S, Taheri JB, Tennant M, et al. Relationship Between Mothers' Knowledge and Attitude Towards the Importance of Oral Health and Dental Status of their Young Children. Oral Health Prev Dent. 2018;16:265-70.

33. Okada M, Kawamura M, Kaihara Y, et al. Influence of parents' oral health behaviour on oral health status of their school children: an exploratory study employing a causal modelling technique. Int J Paediatr Dent. 2002:12:101-8.

34. Hessari $H$, Vehkalahti MM, Eghbal MJ, et al. Oral health and treatment needs among 18-year-old Iranians. Med Princ Pract. 2008;17:302-7.

35. Chung LH, Gregorich SE, Armitage GC, et al. Sociodemographic disparities and behavioral factors in clinical oral health status during pregnancy. Community Dent Oral Epidemiol. 2014;42:151-9.

36. Moimaz SAS, Fadel CB, Lolli LF, et al. Social aspects of dental caries in the context of mother-child pairs. J Appl Oral Sci. 2014;22:73-8.

37. Sanders AE, Spencer AJ, Stewart JF. Clustering of risk behaviours for oral and general health. Community Dent Health. 2005:22:133-40.

38. Al-Tamimi S, Petersen PE. Oral health situation of schoolchildren, mothers and schoolteachers in Saudi Arabia. Int Dent J. 1998:48:180-6.

39. Ahmadian-Yazdi A, Sanatkhani M. A descriptive survey of the oral health on a group of the Asian pregnant women resident in the UK J MASH DENT SCH. 2003:27(3):93-9.

40. Obstetricians ACo. Gynecologists. Oral health care during pregnancy and through the life span. Committee Opinion No. 569. Obstet Gynecol. 2013;122:417-22.

41. Singhal A, Chattopadhyay A, Garcia Al, et al. Disparities in unmet dental need and dental care received by pregnant women in Maryland. Matern Child Health J. 2014;18:1658-66.

42. Mwangosi IE, Kiango MM. Oral health experience during pregnancy and dental service utilization in Bariadi district. Tanzania. Tanzan J Health Res. 2012;14:146-51.

43. Bayat $F$, Vehkalahti MM, Murtomaa $H$, et al. Why do adults entitled to free or highly subsidized dental services select fully out-of-pocket-paid care? Community Dent Oral Epidemiol. 2010;38:88-95.

44. Machuca G, Khoshfeiz O, Lacalle JR, et al. The influence of general health and socio-cultural variables on the periodontal condition of pregnant women. J Periodontol. 70:779-85.

45. Gil L, Mínguez I, Caffesse R, et al. Periodontal Disease in Pregnancy: The Influence of General Factors and Inflammatory Mediators. Oral Health Prev Dent. 2019;17:69-73.

46. Anil S, Alrowis RM, Chalisserry EP, et al. Oral health and adverse pregnancy outcomes. Emerging trends in oral health sciences and dentistry. IntechOpen: In; 2015. https://doi.org/10.5772/59517.

\section{Publisher's Note}

Springer Nature remains neutral with regard to jurisdictional claims in published maps and institutional affiliations. 